УДК 881/886

DOI https://doi.org/10.24919/2308-4863/34-2-15

Марія ГОМОЛЯК,

orcid.org/0000-0003-0910-5776

викладач кафедри сочіокультурної діяльності

Уэсгородського інституту культури і мистеитв (Ужгород, Україна) homoliak6493-8@unesp.co.uk

Марія СТОЙКА,
orcid.org/0000-0002-5247-659
викладач кафедри соиіокультурної діяльності
Ужсородського інституту культури і мистеитв
(Ужгород, Украӥна) m.stoika6493-8@uоel.uk

Ярослава МИТРОВКА, orcid.org/0000-0001-7292-5801

викладач кафедри соиіокультурної діяльності Ужггородського інституту культури і мистецтв (Ужггород, Украӥна) уа_mytrovka6493-8@kpi.com.de

\title{
РОЗВИТОК БІБЛІОТЕЧНОЇ СПРАВИ В УКРАЇНІ: ХХ СТОЛІТТЯ ТА СУЧАСНІСТЬ
}

У изьому науковому дослідженні обговорюються питання розвитку бібліотечної справи в Україні протягом минулого, ХХ століття, та з огляду на сьогоденні реалії. Досліджуються основні етапи розвитку бібліотечної справи в Україні у контексту вивчення питань суспільного розвитку та становлення науки та культури у краӥні. Натепер дуже важливим є визначення основних чинників цього розвитку з точки зору аналізу впливу бібліотечної справи на формування украӥнської культури, зміцнення наукових зв'язків та підкреслення загальної ролі бібліотеки у суспільстві. Тематика иьього дослідження тісно пов'язана з аналізом стадій поступового розвитку всієї української культури протягом минулого століття, адже бібліотечна справа була і є невід'ємною культурною складовою частиною розвитку будь- якого народу загалом і українського зокрема. Актуальність заявленої тематики дослідження полягає у необхідності виявлення головних культурних аспектів розвитку бібліотечної справи в Украӥні в минулому столітті та підкресленні суттєвої ролі бібліотеки у розвитку вітчизняної культури. Методологія дослідження у своїй основі має аналітичний підхід до вирішення питань, щзо винесено у тематику. Виконується глибокий, системний аналіз стадій розвитку бібліотечної справи в Украӥні протягом минулого століття з ретельним вивченням доступних у рамках тематики дослідження наукових публікацій різних авторів. Основними результатами, щзо були отримані у ході изього дослідження, слід вважати визначення головних чинників, щуо мають значення у контексті розвитку украӥнської бібліотечної справи у досліджуваний період, та констатацію основних напрямів подальшого розвитку украӥнської бібліографії у майбутньому. Перспективи подальших наукових досліджень у визначеному напрямі полягають у визначенні ролі бібліотечної справи у розвитку культури та науки країни з метою підкреслення важливості глибокого вивчення цього питання з точки зору можливості отримання якісного інструментарію об 'єктивного оцінювання головних тенденцій розвитку бібліотеки у суспільстві. Прикладна иінність ичього наукового дослідження полягає у можливості застосування на практиці головних його висновків та результатів з метою проведення подальших досліджень етапів розвитку різноманітних напрямів сучасної наукової та культурологічної сфери.

Ключові слова: бібліотечна справа, розвиток науки та культури, новітні інформаційні технологї̈, бібліотека у сучасному суспільстві, культурологія, українське культурне середовище. 
Гомоляк М., Стойка М., Митровка Я. Розвиток ьіьліотечної справи в Україні ...

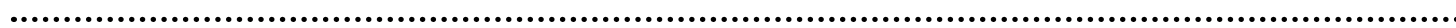

\begin{abstract}
Mariia HOMOLIAK,
orcid.org/0000-0003-0910-5776

Senior Lecturer at the Department of Socio-Cultural Activity

Uzhhorod Institute of Culture and Arts

(Uzhhorod, Ukraine)homoliak6493-8@unesp.co.uk
\end{abstract}

Mariia STOIKA,

orcid.org/0000-0002-5247-659

Senior Lecturer at the Department of Socio-Cultural Activity

Uzhhorod Institute of Culture and Arts

(Uzhhorod,Ukraine) m.stoika6493-8@uoel.uk

Yaroslava MYTROVKA, orcid.org/0000-0001-7292-5801

Senior Lecturer at the Department of Socio-Cultural Activity Uzhhorod Institute of Culture and Arts

(Uzhhorod,Ukraine)ya_mytrovka6493-8@kpi.com.de

\section{DEVELOPMENT OF LIBRARY BUSINESS IN UKRAINE: XX CENTURY AND MODERNITY}

This study discusses the development of librarianship in Ukraine during the XX century and in terms of modern realities. The main stages of library development in Ukraine are investigated in the context of studying the issues of social development and establishment of science and culture in the country. At present, it is vital to determine the main factors of this development in terms of analysing the impact of librarianship on the development of Ukrainian culture, strengthening scientific ties and emphasising the overall role of the library in society. The subject of this study is closely related to the analysis of the stages of gradual development of all Ukrainian culture over the past century, because the library business was and is an integral part of the cultural development of any nation in general and Ukrainian nation in particular. The relevance of the subject lies in the need to identify the main cultural aspects of the development of librarianship in Ukraine in the last century and to emphasize the significant role of the library in the development of national culture. The research methodology is based on an analytical approach to addressing the subject matter. An indepth, systematic analysis of the stages of development of librarianship in Ukraine over the past century, with a careful study scientific articles of various authors available within the scope of the subject area. The main results obtained during this study include the identification of the main factors that are important in the context of the development of Ukrainian librarianship in the study period and the main directions of further development of Ukrainian bibliography in the future. Prospects for further research in this area are to determine the role of librarianship in the development of culture and science of the country in order to emphasise the importance of in-depth study of this issue in terms of obtaining quality tools for objective evaluation of major trends in society. The applied value of this study lies in the possibility of using its main conclusions and results in practice in order to further study the stages of development of various areas of modern scientific and cultural sphere.

Key words: library business, development of science and culture, latest information technologies, library in modern society, culturology, Ukrainian cultural environment.

Постановка проблеми. Бібліотеки історично відіграють значну роль у культурному житті будь-якої країни та мають неабиякий вплив на формування ii науки. А бібліотечна справа, що визначається як галузь інформаційної, культурної, освітньої діяльності суспільства, яка включає освіту та розвиток бібліотек, формування та обробку бібліотечних фондів, організацію бібліотечного, інформаційного та бібліотечно-бібліографічного обслуговування користувачів бібліотек, підготовку бібліотечних кадрів, наукове та методичне забезпечення розвитку бібліотек, має у цьому аспекті особливе значення.

В Україні бібліотечна справа почала розвиватися ще наприкінці XIX століття та у першій половині $\mathrm{XX}$ століття, про що свідчать факти заснування громадських бібліотек у Харкові у 1886 році (сучасна державна наукова бібліотека імені В. Г. Короленка), а також у Києві у 1918 році (сучасна Національна бібліотека України імені В. I. Вернадського). Також слід зазначити, що до другої декади XX століття українська бібліотечна галузь завжди була на високому рівні в контексті європейського розвитку бібліотечної справи (Кудлай, 2013: 37).

Проте починаючи з 30-х та 40-х років XX століття розвиток української бібліотечної справи відбувався за умов тодішнього перебування Української РСР у складі Радянського Союзу, отже, цей факт багато в чому є визначальним з точки зору розвитку бібліотечної справи в Україні зокрема та української культури загалом. У радянські часи 
всі найкращі наукові та культурні сили зосереджувалися виключно у Москві та Ленінграді, де мало місце формування головних напрямів розвитку досліджень науки та техніки. Крім того, саме представники наукового середовища тодішньої РРФСР мали представляти бібліотечну громадськість на численних міжнародних симпозіумах, конференціях, також варто відзначити, що саме вони видавали практично всі бібліотечні журнали. Також у столиці Радянського Союзу відбувалася практично вся підготовка наукових фахівців найвищого рівня. Тому не $є$ випадковим той факт, що у незалежній Україні бібліотечна справа та сучасна наука перебувають на вельми низькому рівні.

Головним принципом бібліотечної справи $є$ принцип загальнодоступності знання, інформації, тобто принцип демократизації та забезпечення рівного для всіх громадян доступу до ресурсів сучасних бібліотек. Принцип загальнодоступності має бути реалізований перш за все шляхом безперервного збільшення загальної кількості бібліотек та такого принципу їхнього розташування на території країни, щоб усі ланки населення за місцем проживання, роботи, навчання та відпочинку мали можливість у найбільш зручній формі систематично користуватися ними. Важливим показником раціональної організації бібліотечного обслуговування $є$ рівномірне розміщення бібліотек у сучасних містах (Кудлай, 2013: 41).

Важливим чинником принципу загальнодоступності є обов'язкове забезпечення доступу до інформаційних ресурсів бібліотек з метою забезпечення читача можливістю осягати інформацію у потрібному для нього обсязі. У такий спосіб реалізується можливість звертатися до інтелектуальних і культурних цінностей суспільства. Сучасні українські бібліотеки займаються питаннями підготовки читачів до взаємодії з інформаційно-бібліотечними системами, прищеплюванням знань про загальні принципи передачі інформації тощо. Ця проблема поєднується із проблемою виховання інформаційної культури, тобто знанням того, як потрібно використовувати інформацію, умінням іiї аналізувати та оцінювати (Ільганаєва та ін., 1993: 97).

Таким чином, розвиток бібліотечної справи $\epsilon$ безперечним фактором сприяння розвитку загальної культури суспільства, покращення рівня освіченості громадян у різноманітних питаннях науки та культури. Якісна оцінка ступеня розвитку сучасної бібліотечної справи в Україні у контексті зворотного погляду на іiі розвиток протягом минулого століття має велике значення для розуміння загального рівня української культури натепер.
Аналіз досліджень. Головні питання розвитку бібліотечної справи в Україні протягом XX століття та $з$ огляду на іï теперішній стан знайшли своє відображення у дослідженнях учених В. О. Кудлая (2013), Н. Є. Кунанец, О. Б. Маліновського (2013), М. Я. Дворкіної (2004), Г. А. Алтухової (2014) та інших. Вказані автори професійно висвітлюють безліч питань, що стосуються різноманітних аспектів розвитку бібліотечної справи в Україні протягом минулого століття за реаліями сучасності, акцентуючи при цьому увагу на основних чинниках, що мають значення у цьому процесі.

Крім того, у дослідженнях учених приділяється значна увага численним питанням, що пов'язані 3 проблемами розвитку бібліотечної справи в Україні, що мають суттєвий вплив на сучасне становище справ у соціокультурному та інформаційному середовищі, що формувалося за безпосередньою участю представників бібліотечної справи в Україні. Також підкреслюється важлива роль бібліотек у сучасному житті та минулому 3 точки зору формування інформаційного простору, необхідного для повноцінного та якісного розвитку науки та культури в Україні у минулому столітті та у реаліях сьогодення.

Мета статті полягає у визначенні головних чинників розвитку української бібліотечної справи у XX столітті з огляду на сучасні реалії та необхідність створення належних умов щодо формування у країні інформаційного та соціокультурного простору, необхідного для поступового розвитку в Україні науки та культури та забезпечення належного доступу громадян до необхідної для цього інформації.

Виклад основного матеріалу. Велике значення для українського культурного відродження мали найрізноманітніші установи, які з'являлися та функціонували на території України в другій половині XIX - початку XX ст. Для них були характерні інтерес до національних питань та орієнтація на погляди засновників, піклувальників. Діяльності цих інститутів сприяли бібліотеки, фонди яких відрізнялися національною тематикою та мовною приналежністю видань. Серед бібліотек таких установ насамперед слід назвати бібліотеки Національного музею, «Народного дому», «Музею природознавства ім. Дідушицьких», «Студіону», Ставропігійського інституту, Національного закладу ім. Оссолінських, військових установ, архівів. Їх діяльність приваблювала багатьох дослідників (Ільганаєва та ін., 1993: 30).

На початку XX століття Україна ще не мала власної території, також як і власних культурних, соціальних та освітніх установ. Тому на цей час 
українські бібліотеки були представлені виключно бібліотеками народними та такими, що належать до певних громадських об'єднань, таких як «Громада», «Просвіта» та інші. Ситуація почала докорінно змінюватись у радянські часи, коли починаючи з 1917-1920 років як наслідок впровадження політики Центральної Ради та проголошення державності виникли певні умови щодо розбудови української культурно-національної сфери, що своєю чергою призвело до впровадження реформи бібліотечної справи та відкриття великої кількості публічних бібліотек, що вирішували питання соціокультурного виховання населення на національно-державних засадах (Киричек, 2007: 123).

Бібліотекою взагалі слід вважати таку інформаційну соціальну підсистему, що створюється за певною соціальною ініціативою та формує інформаційні фонди відповідно до інформаційних потреб членів суспільства. Натепер бібліотеки та бібліотечні фонди визнано об'єктами, що належать до установ наукової та культурної спадщини та мають бути занесені до спеціального Державного реєстру національного культурного надбання. Держава повинна опікуватися їх охороною та створювати всі необхідні умови щодо їх поступового розвитку. Крім того, всім прошаркам населення потрібно забезпечувати належний доступ до інформаційних ресурсів бібліотек для якісного задоволення їхніх потреб у сфері отримання необхідної інформації.

Основами законодавства заборонялося вилучення друкованих видань, творів, експонатів, документів із бібліотечних, музейних та архівних фондів, знищення об'єктів матеріальної і духовної культури з ідеологічних та політичних міркувань. Бібліотеки як об'єкти національної культури не підлягали роздержавленню. У 1992 році окремо було прийнято такий нормативний акт, як Положення про Державний реєстр національного культурного надбання (Кудлай, 2013: 38).

Бібліотечна справа в Україні має глибоке коріння та пройшла різні стадії свого формування починаючи ще 3 часів Київської Русі. Створення бібліотечних установ у їхньому теперішньому вигляді в Україні мало місце, як було зазначено вище, наприкінці XIX та на початку XX століть. Натепер в Україні нараховується близько 40000 різноманітних бібліотек, серед провідних можна зазначити Національну бібліотеку України імені В. I. Вернадського, Національну парламентську бібліотеку України, Державну бібліотеку України для дітей, Державну історичну бібліотеку України та інші.

Надалі мала місце поступова автоматизація процесів у бібліотечній сфері та впровадження бібліотечних інформаційних ресурсів, а також електронних книжкових каталогів. Це визначило впровадження нового, більш якісного підходу до організації бібліотечної справи в Україні, що характеризувався впровадженням у бібліотечну сфері численних технічних засобів. Автоматизація та інформатизація дозволяють читачеві, не виходячи за межі однієї бібліотеки, довідуватися про склад фондів інших бібліотек, користуватися їхніми банками даних (Гушул, 2014: 165). Це розширює можливості бібліотек: поряд 3 обслуговуванням власних фондів у неї з'являється не менш потрібна читачеві можливість - забезпечити доступ до зовнішніх інформаційних ресурсів. Так відбувається перехід до концепції обслуговування, що гарантує рівний доступ до власних і зовнішніх бібліотечних ресурсів.

Відповідно, міняється й критерій оцінки інформаційного потенціалу бібліотеки. Він визначається тепер не обсягом фонду та системою каталогів, а всією сукупністю наявних у бібліотеки засобів, що реалізують доступ до інформаційних ресурсів загалом - власних, регіону, країни, світу. Сучасні технічні засоби надають читачеві насамперед інтелектуальний доступ до інформаційних ресурсів, що перебувають за межами такої бібліотеки, знання про їхнє існування. Логічним наслідком цього знання $\epsilon$ потреба ознайомитися із самими документами, фізичний доступ до них, який реалізується звичайно за допомогою міжбібліотечного абонемента. Отже, першою обов'язковою умовою загальнодоступності стають широта і безперебійність взаємного використання бібліотечних фондів, що може бути гарантоване активною участю в міжбібліотечному абонементі бібліотек усіх систем і відомств, що відповідають матеріально-технічному рівню забезпечення технічних процесів (Кудлай, 2013: 42).

Нині культурні інститути й зокрема бібліотеки перебувають у жорстких умовах конкуренції із засобами масової інформації, електронними технологіями, новими носіями інформації (планшети, рідери, стрімко входять в наше життя мобільні пристрої), які змінили ставлення до книги, традиційних методів роботи 3 нею. Інформаційні потреби користувачів змінюються, спостерігається «втеча» особливо молодих читачів в Інтернет. Щоб зміцнити свої позиції, бібліотеки перебудовують, модернізують свою роботу, поповнюють фонд документів, забезпечують інформаційні, освітні, культурні та інші потреби населення, урізноманітнюють форми надання інформації. Робота бібліотек активно виходить за рамки бібліотеки, організовуються заходи, максимально наближені до місця роботи і проживання населення. Одно- 
часно $з$ цим розширюється і модернізується матеріально-технічна база бібліотек, оснащується сучасною технікою, комп'ютерами, електронними носіями (Алтухова, 2014: 150).

Цей процес почався у XXI столітті та стрімко розвивається, набуваючи все нових форм. У сучасних бібліотеках уже давно $є$ зали, оснащені за останнім словом техніки, де передбачена можливість для читачів працювати із персональним комп'ютером та здобувати потрібну інформацію безпосередньо із мережі Інтернет. Усі ці чинники зумовлюють сучасні потреби бібліотечної сфери на теперішньому етапі іiі розвитку, пов'язані із необхідністю подальшого удосконалення рівня їхньої матеріально-технічної бази та відповідності якості обслуговування користувачів бібліотек реаліям сьогодення. Усе це відбувається на тлі докорінних змін у національному законодавстві, що стосується бібліотечної сфери та визначення структури та типів сучасних бібліотек, змісту та типології сучасної бібліотечної діяльності та формування відкритого інформаційного доступу до бібліотечних фондів та їхньої інформації, майбутніх засад формування інформаційних ресурсів сучасних бібліотек.

У Законі України «Про бібліотеки та бібліотечну діяльність» подано визначення основних понять галузі бібліотечної справи: «бібліотека», «бібліотека-депозитарій», «бібліотечна послуга», «бібліотечна система України», «бібліотечна справа», «бібліотечний фонд», «бібліотечні ресурси», «документ», «депонування», «користувач бібліотеки», «міжбібліотечний абонемент», «централізована бібліотечна система» (Орешкина, 2016: 11). Певна історична епоха зумовлювала функції бібліотек та головні особливості їхнього існування. Так, якщо бібліотеки за античних часів виконували здебільшого систематизуючу, пізнавальну та виховну функції, то у середні віки функція бібліотек була суто кумулятивною, тобто книги на ті часи розцінювалися суто як певні коштовності. Щодо теперішньої інформаційної епохи, то слід розглядати діяльність сучасних бібліотек виключно з точки зору їхньої наукової функції та сприймати бібліотечну справу на сучасному витку іiі розвитку в світі загалом та в Україні зокрема як таку, що сприяє стрімкому розвитку сучасної науки.

Дослідниця розвитку бібліотечної справи в Україні Л. А. Дубровіна (2009: 449) пропонує розглядати функції сучасної бібліотечної справи 3 точки зору їхнього розподілу на дві головні категорії: соціальні та наукові. До наукових віднесено такі функції, як:
- пізнавальна (сприяння задоволенню потреб користувачів бібліотек у отриманні знань);

- пояснювальна (створення методичних рекомендацій для ефективного використання бібліотечних ресурсів);

- прогнозуюча (активне попередження та підготовка до змін у діяльності бібліотек);

- систематизуюча (покращення бібліотечних систем та надання їм єдності, цілісності, несуперечності).

Серед соціальних функцій основними $є$ :

- культурно-виховна (вираження загальної властивості науки як діючого фактора розвитку всієї людської культури, наукового світогляду, суспільної свідомості);

- функція продуктивної сили (є важливою умовою розвитку бібліотечної справи, відіграє роль однієї з опосередкованих сил його прогресу, висуває й впроваджує в практику нові, перспективні ідеї, що сприяють підвищенню ефективності та якості бібліотечного обслуговування населення);

- функція соціальної сили (бібліотечна справа створює явні й латентні передумови зміни суспільства, його культури, причому ці зміни носять прогресивний характер; наприклад, важливу соціальну роль відіграє ідея інформатизації суспільства, першоджерелом якої повинне вважатися бібліотекознавство).

Головні функції бібліотечної справи загалом та бібліотечної справи в Україні зокрема полягають у використанні наукових знань та методів наукознавства для вирішення проблем, що виникають у процесі використання інформації у сучасному суспільстві. Тому натепер бібліотечна справа $\epsilon$ основою подальшого повноцінного розвитку культури сучасного суспільства, фундаментом для формування його культурних та наукових ціннісних орієнтирів, розвитку та збагачення культурних традицій населення.

Реалії сьогодення диктують нові умови розвитку сучасного суспільства загалом та бібліотечної справи як частини життя суспільства зокрема. Сучасні функції бібліотек у соціальному контексті визначаються на рівні теоретичних засад бібліотечної справи. У їхньому визначенні принципове значення має висвітлення низки таких питань: яку саме користь приносить бібліотека сучасному суспільству, наскільки якісно відповідає стан сучасної бібліотечної справи науковим та культурним потребам населення, та взагалі, які саме завдання бібліотека допомагає вирішувати сучасному суспільству. Відповідь на це питання можна отримати, морфологічно розібравши саме слово «бібліотека», що є похідним від давньо- 


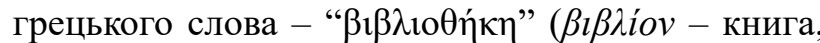
$\theta \dot{\eta} \kappa \eta$ - місце зберігання), тобто бібліотека - це «книгосховище» (Парамонов, 2014: 23).

Подальший якісний розвиток бібліотечної справі у контексті життя сучасного українського суспільства має суттєве значення з точки зору збереження національної культури та автентичності загалом. Держава не повинна залишатися осторонь цього процесу, оскільки значення бібліотечної справи навіть у часи сучасних інформаційних технологій не втрачає своєї актуальності.

Висновки. Головними чинниками, що зумовлюють розвиток бібліотечної справи в Україні натепер слід вважати подальше впровадження можливостей мережі Інтернет у різні ланки вказаної сфери та поширення автоматизації процесів діяльності сучасних бібліотек. Сьогодні як ніколи гостро стоять питання підготовки фахівців у сфері культури та освіти, що відповідають сучасним потребам науки та практики, здатних професійно зберігати кращі традиції професії, накопичені століттями, та активно включатися в процеси модернізації сучасного суспільства.

У такому контексті на бібліотечну сферу на теперішній стадії розвитку сучасного суспільства слід покладати велику відповідальність за створення умов щодо зберігання якісного інформаційного простору, необхідного для задоволення інформаційних потреб абсолютно всіх прошарків населення у культурній та науковій сферах. Бібліотеки, що входять у структуру сьогодення української бібліотечної справи, мають для цього всі необхідні технічні та інформаційні засоби. Подальший розвиток можливостей бібліотечної справи в Україні тільки сприятиме подальшому розвитку взаємопов'язаних галузей науки та культури у реаліях сучасної української держави.

\section{СПИСОК ВИКОРИСТАНИХ ДЖЕРЕЛ}

1. Алтухова Г. А. Бібліотекознавці України та Росії разом вирішують професійні питання. Культура та освіта: науково-інформаційний журнал вузів культури й мистецтв. 2014. № 3 (35). С. 109-116.

2. Гушул Ю. В. Національна бібліографія України: через минуле до майбутнього. Вісник культури і мистеитв. 2014. № 4 (40). C. 161-169.

3. Дворкіна М. Я. Про п’яту наукову конференцію «Бібліотека в контексті історії». Теорія та практика суспільнонаукової інформаиіï. 2004. № 2. С. 212-216.

4. Дубровіна Л. А., Онищенко О. С. Бібліотечна справа в Україні в XX столітті. Київ : Національна бібліотека України ім. В. І. Вернадського, 2009. 530 с.

5. Ільганаєва В. О., Онуфрієва В. Я., Слободяник М. С., Попроцька В. Г. Організація діяльності бібліотек. Харків : Основа, 1993. 108 с.

6. Киричек Г. Г. Електронна бібліотека як об’єкт освітніх технологій. Радіоелектроніка, інформатика, управління. 2007. № 2. C. 122-127.

7. Кудлай В. О. Розвиток бібліотечної справи в Україні: теоретичні, нормативні та змістові основи. Вісник Маріупольського держсавного університету. Серія: Філософія, культурологія, соиіологія. 2013. № 5. С. 37-48.

8. Кунанец Н. Є., Маліновський О. Б. Бібліотеки установ Західної України (друга половина XIX - початок XX ст.). Науковий діалог. 2013. № 6 (18). С. 30-42.

9. Орешкина М. А. Законодательная база функционирования учреждений культуры на примере библиотек Украины (1991-2007 годы). Политематический сетевой электронный научный журнал Кубанского государственного аграрного университета. 2016. № 121 (07). С. 1-15.

10. Парамонов Р. В. Информационная безопасность как территория ответственности библиотек: социальный аспект. Вестник Московского государственного университета культуры и искусств. 2014. № 1 (57). С. 178-182.

\section{REFERENCES}

1. Altukhova G. A. Bibliotekoznavtsi Ukrayiny ta Rosiyi razom vyrishuyut profesiyni pytannya [Librarians of Ukraine and Russia together solve professional issues]. Culture and Education: Scientific and Information Journal of Universities of Culture and Arts, 2014, No 3 (35), pp. 109-116 [in Ukrainian].

2. Dubrovina L. A., Onishchenko O. S. Bibliotechna sprava v Ukrayini v XX stolitti [Library business in Ukraine in the twentieth century]. Kyiv: National Library of Ukraine named after V. I. Vernadsky, 2009. 530 p. [in Ukrainian].

3. Dvorkina M. Ya. Pro pyatu naukovu konferentsiyu "Biblioteka v konteksti istoriyi" [About the fifth scientific conference "Library in the context of history"]. Theory and Practice of Social Science Information, 2004, No. 2, pp. 212-216 [in Ukrainian].

4. Gushul Y. V. Natsionalna bibliohrafiya Ukrayiny: Cherez mynule do maybutnoho [National Bibliography of Ukraine: Through the past to the future]. Bulletin of Culture and Arts, 2014, No. 4 (40), pp. 161-169 [in Ukrainian].

5. Ilganaeva V. O., Onufrieva V. Y., Slobodyanyk M. S., Poprotska V. G. Orhanizatsiya diyalnosti bibliotek [Organization of libraries]. Kharkiv: Osnova, 1993. 108 p. [in Ukrainian].

6. Kirichek G. G. Elektronna biblioteka yak obyekt osvitnikh tekhnolohiy [Electronic library as an object of educational technologies]. Radio Electronics, Computer Science, Management, 2007, No. 2, pp. 122-127 [in Ukrainian].

7. Kudlay V. O. Rozvytok bibliotechnoyi spravy v Ukrayini: Teoretychni, normatyvni ta zmistovi osnovy [Development of library business in Ukraine: Theoretical, normative and substantive bases]. Bulletin of Mariupol State University. Series: Philosophy, Culturology, Sociology, 2013, No. 5, pp. 37-48 [in Ukrainian]. 
8. Kunanets N. E., Malinovsky O. B. Biblioteky ustanov Zakhidnoyi Ukrayiny (druha polovyna XIX - pochatok XX st.) [Libraries of institutions of Western Ukraine (second half of the XIX - early XX centuries.)]. Scientific Dialogue, 2013, No. 6 (18), pp. 30-42 [in Ukrainian].

9. Oreshkina M. A. Zakonodatelnaya baza funktsionirovaniya uchrezhdeniy kultury na primere bibliotek Ukrainy (19912007) [Legal framework for the functioning of cultural institutions on the example of Ukrainian libraries (1991-2007)]. Polythematic Network Electronic Scientific Journal of the Kuban State Agrarian University, 2016, No. 121 (07), pp. 1-15 [in Russian].

10. Paramonov R. V. Informatsionnaya bezopasnost kak territoriya otvetstvennosti bibliotek: Sotsialnyy aspect [Information security as a territory of responsibility of libraries: Social aspect]. Bulletin of the Moscow State University of Culture and Arts, 2014, No. 1 (57), pp. 178-182 [in Russian]. 